Portland State University

PDXScholar

$5-27-2017$

Best Practices to Reduce Supplier Power Asymmetries for Microbusinesses

Danielle Lessler

Portland State University

Follow this and additional works at: https://pdxscholar.library.pdx.edu/honorstheses

Let us know how access to this document benefits you.

Recommended Citation

Lessler, Danielle, "Best Practices to Reduce Supplier Power Asymmetries for Microbusinesses" (2017).

University Honors Theses. Paper 378.

https://doi.org/10.15760/honors.375

This Thesis is brought to you for free and open access. It has been accepted for inclusion in University Honors Theses by an authorized administrator of PDXScholar. Please contact us if we can make this document more accessible: pdxscholar@pdx.edu. 


\title{
Best Practices to Reduce Supplier Power Asymmetries for Micro Businesses
}

\author{
By \\ Danielle Lessler \\ An undergraduate honors thesis submitted in partial fulfillment of the requirements for the
} degree of

Bachelor of Arts

in

University Honors

Supply Chain Management

and

Accounting

Thesis Advisor

Dr. Lihong Qian

Portland State University

2017 


\section{Table of Contents}

$\begin{array}{ll}\text { Table of Contents } & 1\end{array}$

$\begin{array}{lr}\text { Introduction } & 3\end{array}$

$\begin{array}{ll}\text { Power and Power Dynamics: An Overview } & 4\end{array}$

$\begin{array}{ll}\text { Power } & 4\end{array}$

$\begin{array}{ll}\text { Power Dynamics } & 4\end{array}$

Who Has Power When? $\quad 5$

Relationship Types $\quad 5$

$\begin{array}{ll}\text { Buyer Sourcing Options } & 6\end{array}$

Solutions to Power Imbalances Between Micro Businesses and their Suppliers 8

$\begin{array}{ll}\text { Value Appropriation and Management Styles } & 8\end{array}$

$\begin{array}{ll}\text { Sociological Perspective } & 8\end{array}$

$\begin{array}{ll}\text { Motivational Withdrawal } & 8\end{array}$

Extension of Power Network 9

Emergence of Status $\quad 9$

Coalitions and Strategic Alliances $\quad 9$

$\begin{array}{ll}\text { Other Supply Chain Perspectives } & 10\end{array}$

$\begin{array}{ll}\text { Client Overview and Recommendations } & 11\end{array}$ 
Microbusiness Defined

Power Dynamics for Microbusinesses

Client Profile

Client Supplier Information

Client-Specific Recommendations

Conclusion and Future Research

Figure 1 - Business Census Data

Figure 2 - Cox Power Matrix

Figure 3 - Client Supplier Information 


\section{Introduction}

Buyer and supplier power dynamics can have immense effects on the outcomes of transactions and relationships. These effects can make or break a business, and thus, knowing how to manage them is essential to healthy business operations. This knowledge is particularly important for microbusinesses, defined as having 1-4 employees including the owner, because they inherently exhibit many of the attributes associated with the weaker player in buyer-supplier dynamics. In order to overcome the negative consequences that come with being the weaker player in a relationship, a microbusiness often has to work harder than other firms in the hope of securing favorable supply. Unfortunately, existing literature focuses on organizations that are larger than micro, or even small-sized firms, thus our understanding about the effect of the buyer-supplier relationship on a microbusiness is rather limited. Even less is our understanding about the strategies that a microbusiness can use to navigate unfavorable buyer-supplier power dynamics. The purpose of this thesis is to fill this gap, exploring power dynamics for microbusinesses and assessing if and how existing research can be applied to these unique entities. Using an established sociological framework, this thesis suggests some power balancing methods that microbusinesses can use to improve their position in their supply chain relationships to extract maximum value from their supplier relationships. This thesis aims to provide practical actions for microbusiness abundant in Portland and beyond. 


\section{Power and Power Dynamics: An Overview}

\section{Power}

"Power is at the heart of all business relationships" (Cox, 2001). It is defined as "the amount of resistance" one party can overcome before the other party yields to their demands (Emerson, 1962). Hunt \& Nevin wrote that "the concept of power is considered central in understanding the means by which one channel member can change or modify the behavior of another member within its channel of distribution" (1974).

There are five sources of power: reward, expert, legitimate, referent, and coercive (French \& Raven, 1959). The first four are considered non-coercive forms of power and can be separated from coercive power because they do not involve negative consequences as a result of non-performance (Hunt \& Nevin, 1974). Expert power is how much knowledge one firm has over the other in a given situation, legitimate power is the belief that another firm has authority Types of power are: technical, knowledge, social, logistic, administrative, historic, economic, technological, and political (as cited in Johnsen \& Ford, 2008, p.473). A firm's "possession of resources determines the player's power" and the amount of power it has is determined by how "valuable, rare, inimitable, and nonsubstitutable" those resources are (as cited in Bastl, Choi, \& Johnson, 2013).

\section{Power Dynamics}

The complexity of relationships make examining a relationship and defining its power dynamics extremely challenging. One of the difficulties with understanding power between two parties is that power is inextricably linked with dependence. The more a party depends on resources another party has, the less power they have to gain access to the things they need or want. The dependence of one party is "directly proportional" to the other party's "motivational investment" in the goals of that party, and "inversely proportional to the availability of those goals" outside of the dyadic relationship (Emerson, 1962).

Another difficulty with understanding power dynamics is that relationship dynamics are constantly changing. Every action or inaction on behalf of either party can shift the balance; additionally there are multiple external forces that can change the power dynamic. These forces include political, economic, sociocultural, technological, environmental, and legal factors. 
Power dynamics have been studied in many supply chain contexts by many researchers; however, it is impossible to study all of the factors that affect power dynamics simultaneously, and as such, researchers have been forced to focus on specific characteristics in their studies. Characteristics that can affect power in relationships include: the saturation of buyers or suppliers in the market, the percentage market share held by the buyer or supplier, the level of dependence the buyer or supplier has on the other party for revenue, switching costs, the attractiveness of the buyer or suppliers' account to the other party, the originality of the product or service offered, the cost of searching for a buyer or supplier, and the amount of information that the buyer or supplier has about the other party (Cox, 2004). Other factors that affect power and cause asymmetries include firm size, (Villena \& Craighead, 2017); relational capital, (Villena \& Craighead, 2017), (Dyer \& Singh, 1998); and legal bonds (Carey et al., 2011).

Additionally, the economic and social nature of buyer-supplier exchanges (Villena \& Craighead, 2017) make power dynamics more complex. Behind every business relationship are people that add or take away relational "rents" (Dyer \& Singh, 1998) in addition to the economic aspects of the exchange. The factors that can affect power dynamics in relationships listed above can be related to either economic or social aspects of these exchanges. (Villena \& Craighead, 2017).

\section{Who Has Power When?}

There are four areas under which a buyer-supplier relationship can fall: buyer dominance, supplier dominance, firm interdependence, and firm independence. When the buyer is dominant, buyer power is high and supplier power is low. When the supplier is dominant, supplier power is high and buyer power is low. When the firms are interdependent, both the buyer and supplier have high levels of power in the relationship, and when firms are independent, both buyer and supplier power in the relationship are low (Cox, 2004). Figure 2, the power matrix, shows conditions under which each of these scenarios can occur. It is unrealistic to expect buyers to shift all of their relationships to a place where they are dominant, or in an equal place to their suppliers; however, buyers should work to move relationships to a place where they get the best quality and cost from their suppliers (Cox, 2001).

\section{Relationship Types}

Within the power matrix, relationships can be adversarial or non-adversarial and arm's length or collaborative (Cox, 2004).

Typically, arm's length relationships have: "nonspecific asset investments, minimal information exchange...separable technological and functional systems within each firm that are characterized by low levels of interdependence and low transaction costs and minimal 
investments in governance mechanisms" (Dyer \& Singh, 1998). Although much of the supply chain literature is focused on collaborative relationships, arm's length relationships are typical of most supply chain relationships and tend to be short-term (Cox, 2004).

Collaborative relationships are characterized by "relational rents," defined as "supernormal profit jointly generated in an exchange relationship that cannot be generated by either firm in isolation and can only be created through the joint idiosyncratic contributions of the specific alliance partners." Relational rents can be accrued over time, and can provide significant advantages for the partners (Dyer \& Singh, 1998). Collaboration is unique because it encompasses both economic and social aspects of exchanges. In collaboration, buyers and suppliers share detailed information about their operational processes, future developments and needs, and link their operations (Cox, 2004).

\section{Buyer Sourcing Options}

According to Cox, before buyers can implement their sourcing options, they must understand the power dynamic in the relationship, the external environmental factors that can affect the relationship, and the type of management style they should use for the sourcing method they choose (2004).

In order to diversify buyer risk, buyers can use "short-term competitor or longer-term collaboration" to achieve their sourcing goals (qtd. In Cox, 2004). There are four different sourcing options for buyers: supplier development, supplier selection, supply chain management, and supply chain sourcing. The first two are concerned specifically with first-tier suppliers with supplier development representing a collaborative, long-term approach to sourcing and supplier selection representing short-term contracting type relationships that are typical of most sourcing relationships (Cox, 2004).

Supplier selection involves a buyer looking at available suppliers and deciding which will best meet their needs whilst balancing their economic restrictions. The buyer will give the supplier information about their specific needs for that product, but will have no involvement in how their order is executed and little involvement in any kind of supply innovation (Cox, 2004). This is the easiest sourcing method for microbusinesses as it requires the least amount of resource investment and allows the firm to stay agile; however, its reactive instead of proactive nature means that a firm cannot extract as much value from their supply chain.

Supplier development is a proactive approach to sourcing that involves shifting the buyer-supplier relationship from arms-length to collaborative. In this type of sourcing, the buyer 
and supplier will share information, creating transparency and allowing the parties to make specific changes to their businesses to extract maximum value from the relationship (Cox, 2004).

The other sourcing options become especially relevant for larger organizations with more than one tier of suppliers. However, it is worth noting that the smaller amount of complexity that can come with managing only one tier of suppliers can be an immense benefit to microbusinesses. Supply chain management represents a proactive method that works to develop suppliers at every level of the supply chain. It requires vast investments of both time and resources, significant involvement of buyers and a long-term commitment to their suppliers. Supply chain sourcing involves selecting suppliers throughout the supply chain as opposed to merely first-tier suppliers and, like supplier selection is usually transacted at arms-length.

\section{Microbusiness Defined}

A microbusiness is defined as a company of 1-4 people including the owner. According to the 2014 US Census, microbusinesses made up $61.77 \%$ of all US firms, and $4.91 \%$ of employment. In Oregon, $59.15 \%$ of firms were microbusinesses and they made up $6.13 \%$ of Oregon employment. At the end of 2014, Oregon was home to $1.48 \%$ of US microbusinesses and $1.25 \%$ of the US population (at the beginning of 2015). This is significant because it means that Oregon's microbusinesses are employing more than the US average and more than their share of the US population. See Figure 1 for further details.

\section{Power Dynamics for Microbusinesses}

The factors that affect power dynamics listed above included external factors, market factors, and specific business relationship factors.

External factors can benefit microbusinesses, or they can be particularly devastating because microbusinesses may not have capital to wait out market changes, adjust to of affect political or regulatory changes, or adapt to fast-paced technological changes.

Market factors are impossible for a microbusiness to control: unlike vast corporations, they simply don't have the capital to buy out other players in their industry to change the market dynamics or quash their competitors. In fact, microbusinesses are vulnerable to this type of buyout or takeover themselves. One factor that is an advantage for microbusinesses is their ability to be agile in the market. Unlike larger businesses who many have entered into extensive contracts to secure supply, microbusinesses are more likely to be able to pivot and thus secure more favorable supply when necessary. Additionally, Microbusinesses are also in a unique position to be developed by their customers and as such can create high switching costs for those customers. 
Relationship-specific factors are where a microbusiness has the most control. Given their small size, they can build close relationships with their suppliers because more often than not, the same person is in charge of the account which is more conducive to building trust in the relationship. This means it is easier to build the relational "rents" referred to by Dyer \& Singh (1998) and Villena \& Craighead (2017). However, if there are personality clashes between the buyer and supplier, this can work against a microbusiness because they cannot simply replace the account manager at a whim. 


\section{Solutions to Power Imbalances Between Firms and their Suppliers}

There are two potential ways for microbusinesses to work with power asymmetries in their supplier relationships: understanding or management.

\section{Value Appropriation and Management Styles}

Understanding where a firm stands in relation to their supplier can help them decide what type of relationship they should foster (Cox, 2004). A firm can use this understanding to be reactive and understand the options they have when communicating with their suppliers or they can use understanding to be proactive and develop management styles and relationships that will leverage their position to build a strong supply chain.

\section{Sociological Perspective}

Alternatively, microbusinesses can try to change the balance of power in their relationships with their suppliers. Because business to business relationships demand personal interaction, we can look to sociology to formulate potential recommendations for microbusinesses who are working with power imbalances. It is important to understand that because power is inextricably linked with dependence, a firm can plan their strategy, but only mediate the other party's response. Emerson states that his sociological research can be applied "to more complex community relations" (1962). This, and the personal nature of business relationships means that the sociological research is an ideal framework to apply to business to business relationships. Emerson suggests that there are four ways to change the balance of power in a relationship.

\section{Motivational Withdrawal}

The first is "motivational withdrawal" of the weaker, more dependent party. This can happen when the weaker party can no longer cope with the requirements of the other party; parties tend to distance themselves from relationships that are consistently not in their favor (1962). When a stronger firm uses its power, it makes the weaker firm resent them and "reduces...willingness to cooperate" (qtd. in Crook \& Combs, 2007). Although not something the weaker party can control, it is important for powerful firms to mind when and how they exercise their power because it may be enough for the weaker firm to withdraw from the relationship altogether. 


\section{Extension of Power Network}

Emerson's second method for changing the balance of power in a relationship uses the idea that interactions between two players affect, and are affected by, their relationships with other parties that they are connected to. Increasing the size of a network decreases the power of the strong and can make relationships more balanced. This method involves the "diffusion of dependency into new relations in a network" (1962). In the world of business, this addition of players is not necessarily something that can be decided by any one player in the industry and is more a function of how accessible the market is to enter.

\section{Emergence of Status}

Emerson's third method for changing the balance of power in a relationship is "emergence of status." Weaker players can increase their power in a relationship by recognizing the powerful player's status and their high value to the relationship. Doing so increases the powerful player's "motivational investment in the relation" (1962). Research on this area in the supply chain management field is lacking, but this could be considered a form of relational capital building and studied further in that context.

\section{Coalitions and Strategic Alliances}

Emerson's fourth method for changing the balance of power in a relationship is for two weaker parties to join together to interact with the stronger party (1962). This relationship can take either of two forms: a coalition (Bastl, Choi, \& Johnson, 2013), or a strategic alliance. The two are distinctly different across four areas: "purpose, focus, duration, and relationship formalization" (Bastl, Choi, \& Johnson, 2013). Coalitions can take place between individuals, interest groups or nations and strategic alliances usually take place across organizations. Both are deliberately constructed, but coalitions are focused on specific issues where the overall goals of each party do not align and each's goal lies outside of the coalition, whereas strategic alliances are focused on overall strategy, where the organizations' goals are aligned with one another. Coalitions are informal, short-term groups, but strategic alliances are formal, highly cooperative, and designed to be long-term, despite inherent instability (Bastl, Choi, \& Johnson, 2013).

The effects of forming coalitions have been studied in a supply chain context. Coalitions are defined as "a temporary, means-oriented alliance among players with different goals" (as cited in Bastl, Choi, \& Johnson, 2013). Coalition forming shifts the dyadic nature of supply chain relationships into triads and larger networks (Bastl, Choi, \& Johnson, 2013). This option is ideal if the two weaker parties can both benefit from their interactions with the stronger party; its focus is on increasing the strength of the weaker parties instead of decreasing the strength of the stronger party (Emerson, 1962). The addition of a third member into the relationship inherently 
changes the nature of the original relationship (Emerson, 1962), (Bastl, Choi, \& Johnson, 2013), and can bring it from an adversarial state to a collaborative one (Bastl, Choi, \& Johnson, 2013). One of the key advantages of being a microbusiness is the ability to pivot whenever the needs of the business demand doing so, and as such, a coalition is ideal for this type of firm because of its short-term, project goal-based nature.

\section{Other Supply Chain Perspectives}

Relational capital is concerned with the social exchange side of buyer-supplier relationships. Size is one of the most discerning factors in power asymmetries from an economic standpoint, but relational capital does not discriminate based on size. Villena \& Craighead studied size and relational capital asymmetries, finding that "a buyer perceives lower benefits whether the buyer is bigger or smaller and when the supplier has higher relational capital" (2017). Relational capital research is still in its infancy and researchers have reached varying conclusions on how much it positively affects performance and its negative aspects. However, it appears that it is important for firms to consider, because "if not effectively managed...[it] can become a liability in the form of perceived opportunism" (Villena \& Craighead, 2016). Building relational capital, or "Shared ambitions, goals, vision and values" can "help foster trust, identification and obligation within the relationship" (Carey et al., 2011).

To manage relational capital, firms should strive to be transparent in their discussions with suppliers, "avoid ambiguity in negotiations," consider how changes to the account will be perceived by the other party (Villena \& Craighead, 2016), ensure that the relationship is governed by legal bonds, and engage in social events outside of what is required by the relationship (Carey et al., 2011). Carey et al. found that "organized social events and team building between buyer and supplier facilitate interaction, enabling buyers to personally evaluate the trustworthiness and commitment of supplier representatives." Relational capital facilitates information sharing between buyer and supplier, leading to better performance and better innovation (2011). It is important to note that although this study was conducted for the most part on large companies and their suppliers, this information is applicable to microbusinesses because they are able to have the same person interact with their suppliers much more consistently than large firms. Additionally, legal bonds have significantly positive effects on the levels of relational capital (Carey et al., 2011). Contracts encourage important communication between parties at the inception of a relationship and provide legal protection to both parties in the event that either the social exchange or economic aspects of relationship fail. 


\section{Power Dynamics and Solutions for Microbusinesses}

\section{Client Profile}

To provide context for how power dynamics affect microbusinesses, the above literature review will be placed in context of a case study. To preserve anonymity, the client to whom we provided consulting to in our Spring term 2017 BA 495: Business Strategy course will be referred to hereafter as "Client."

The Client produces artisan preserves from local Oregon produce including berries and stone fruits. According to the three generic business competencies, the Client's competence is transformation, or "the ability to create innovative supply offerings by adding value to supply inputs and outputs (Cox, 2000). At the time of writing, the Client was a one-person business and had 15 suppliers of various sizes. Some supplier relationships are collaborative and others are arms length. As the Client grows, they will be in a position to implement contracts instead of casually buying when necessary. The majority of the Client's relationships fall into the "supplier selection" category, but vital raw materials relationships fall under "supplier development."

\section{Client Supplier Information}

Most of the Client's supplier relationships are supplier dominant arm's-length relationships, but there are a number of supplier dominant collaborative relationships and one reciprocal collaborative relationship. See Figure 3 for a detailed breakdown of the Client's suppliers and statistics.

During the Client project, the relationship with Supplier B that had been an arms-length relationship with an adversarial element changed and led the Client to seek a new supplier for that product. This product required that the Client incur significant switching costs for re-tooling, but they were planning on re-tooling with Supplier B within the next year. Although the timing of the re-tooling was inconvenient for the Client, ultimately, this Motivational Withdrawal led to a supplier relationship that gives the Client better price, a product that more closely matches their needs, and a supplier who is able to give them the flexibility they need. Supplier B exerted power by showing a lack of flexibility and inability to deliver to the Client which, although not something the Client can directly control, is something the Client can consider when selecting suppliers in the future. This is an example of how supply chain management is not simply about getting the best price for supplies but is about getting "the best products at the best value considering the risks and costs" (Wong, 2016). 


\section{Client-Specific Recommendations}

Our Business Capstone group is providing the Client with a projected purchasing schedule for this year and two future years. This involved working back from sales/ending inventory and using recipes to calculate how much of every supply the Client used in 2016 . The schedule provides a list of supplies and suggests when they should be purchased in order to secure optimum supply price and to take advantage of any volume discounts available. Additionally, the Client can use this schedule to decide whether or not there are suppliers with whom they can make contracts to guarantee specific levels of supply or pricing. Doing this will allow the Client to reduce their cost of goods sold and increase their profit margins. Additionally, it will allow the Client to take advantage of when raw material prices are low because they will have an accurate count of purchasing needs.

When building future relationships, potentially with cold storage suppliers or new raw material suppliers, the Client should consider how important the relational capital side of their relationships are to avoid future relationships that have adversarial elements. In the context of the Client, the more current the information, the easier they can create new products to adapt to the changing environment. Since the Client frequently spends time with their suppliers, including some time spent in a more social context, social capital is naturally built. The Client should seek to build relational rents with suppliers that are currently characterized as arms-length so that collaborative relationships are a possibility in the future. These should initially be coalitions, but the Client can begin to look for opportunities to create a strategic alliance. A coalition would be optimum for the Client at this key time in their growth because they need to maintain flexibility in their supply chain in order to extract maximum value. It is essential that the Client begin implementing legal bonds with appropriate suppliers to protect themselves and because it will help them build relational capital. Finally, continuing to withdraw from relationships, (Motivational Withdrawal), that are not meeting the Client's needs and moving on to relationships that can be built in the way described above is key to securing more favorable supply. 


\section{Conclusion and Future Research}

In conclusion, it is essential for microbusinesses to understand where their supplier relationships fall in the power matrix so that they can decide how best to manage, or change, the imbalance of power in those relationships. In order to manage power and its imbalances, microbusinesses can withdraw from adverse supplier relationships, try to help new entrants into the market to reduce the power of one player, form coalitions or strategic alliances, and work to build relational capital. Now that the Client has a forecast of their materials needs for the next 2 years, they can use legal bonds, motivational withdrawal, and coalitions to help secure ongoing favorable supply that can be flexible. Finally, they can begin to explore strategic alliance opportunities for the long-term.

In the future, this work should be extended to include methodological research. It should consist of a dyadic survey of microbusinesses and their suppliers that asks about perceived power in their buyer-supplier relationships. This will help us to understand whether or not there is a disconnect between how much power microbusinesses think they have and how much they could have. Helping weaker firms understand their power position and how they can leverage their business assets most effectively will help more of them succeed in the long term. 


\section{Appendices}

Figure 1 - Business Census Data

\begin{tabular}{|c|c|c|c|c|c|c|c|c|c|}
\hline \multicolumn{5}{|c|}{ United States } & \multicolumn{5}{|l|}{ Oregon } \\
\hline $\begin{array}{l}\text { Firm } \\
\text { Size }\end{array}$ & $\begin{array}{l}\text { Number } \\
\text { of Firms }\end{array}$ & $\begin{array}{l}\# \text { of } \\
\text { employees }\end{array}$ & $\begin{array}{l}\% \\
\text { firms }\end{array}$ & $\begin{array}{l}\% \\
\text { employment }\end{array}$ & $\begin{array}{l}\text { Firm } \\
\text { Size }\end{array}$ & $\begin{array}{l}\text { Number } \\
\text { of Firms }\end{array}$ & $\begin{array}{l}\# \text { of } \\
\text { employees }\end{array}$ & $\begin{array}{l}\% \\
\text { firms }\end{array}$ & $\begin{array}{l}\% \\
\text { employment }\end{array}$ \\
\hline Total & $5,825,458$ & $121,069,944$ & $100 \%$ & $100 \%$ & Total & 89,739 & $1,444,041$ & $100 \%$ & $100 \%$ \\
\hline $0-4$ & $3,598,185$ & $5,940,248$ & $\begin{array}{r}61.77 \\
\%\end{array}$ & $4.91 \%$ & $0-4$ & 53,085 & 88,546 & $\begin{array}{r}59.15 \\
\%\end{array}$ & $6.13 \%$ \\
\hline $5-9$ & 998,953 & $6,570,776$ & $\begin{array}{r}17.15 \\
\%\end{array}$ & $5.43 \%$ & $5-9$ & 15,499 & 101,631 & $\begin{array}{r}17.27 \\
\%\end{array}$ & $7.04 \%$ \\
\hline 10-19 & 608,502 & $8,176,519$ & $\begin{array}{r}10.45 \\
\%\end{array}$ & $6.75 \%$ & $10-19$ & 9,566 & 127,278 & $\begin{array}{r}10.66 \\
\%\end{array}$ & $8.81 \%$ \\
\hline $20-99$ & 513,179 & $20,121,588$ & $8.81 \%$ & $16.62 \%$ & 20-99 & 7,520 & 270,578 & $8.38 \%$ & $18.74 \%$ \\
\hline $100-499$ & 87,563 & $17,085,461$ & $1.50 \%$ & $14.11 \%$ & $100-499$ & 1,837 & 213,633 & $2.05 \%$ & $14.79 \%$ \\
\hline $500+$ & 19,076 & $63,175,352$ & $0.33 \%$ & $52.18 \%$ & $500+$ & 2,232 & 642,375 & $2.49 \%$ & $44.48 \%$ \\
\hline
\end{tabular}


Figure 2 - Cox Power Matrix

THE ATTRIBUTES OF BUYER AND SUPPLIER POWER

\begin{tabular}{|c|c|c|c|}
\hline \multirow{5}{*}{ 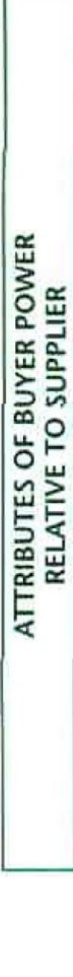 } & \multirow{3}{*}{$\mathrm{HIGH}$} & BUYER DOMINANCE & INTERDEPENDENCE \\
\hline & & $\begin{array}{l}\text { - Few buyers/many suppliers } \\
\text { - Buyer has hight } \% \text { share of total market for supplier } \\
\text { - Supplier is highly dependent on buyer for revenue with } \\
\text { limited alternatives } \\
\text { - Supplier switching costs are high } \\
\text { - Buyers switching costs are low } \\
\text { - Buyers account is attractive to supplier } \\
\text { - Supplier offerings are commoditised and standardised } \\
\text { - Buyer search costs are low } \\
\text { - Supplier has no information asymmetry advantages over buyer }\end{array}$ & $\begin{array}{l}\text { - Few buyers/few suppliers } \\
\text { - Buyer has relatively high \% share of total market for supplier } \\
\text { - Supplier is highly dependent on buyer for revenue with few } \\
\text { alternatives } \\
\text { - Suppliers switching costs are high } \\
\text { - Buyer switching costs are high } \\
\text { - Buyers account is attractive to supplier } \\
\text { - Supplier offerings are not commoditised and customised } \\
\text { - Buyer search costs are high } \\
\text { - Supplier has significant information asymmetry advantages over } \\
\text { bujer }\end{array}$ \\
\hline & & INDEPENDENCE & SUPPLIER DOMINANCE \\
\hline & LOW & $\begin{array}{l}\text { - Many buyers/many suppliers } \\
\text { - Buyer has relatively low } \% \text { share of total market for supplier } \\
\text { - Supplier is not dependent on buyer for revenue and has many } \\
\text { alternatives } \\
\text { - Supplier switching costs are low } \\
\text { - Buyers switching costs are low } \\
\text { - Buyers account is not particularly attractive to supplier } \\
\text { - Supplier offerings are commoditised and standardised } \\
\text { - Buyer search costs are relatively low } \\
\text { - Supplier has anly limited iniormation asymmetry advantage over } \\
\text { buyer }\end{array}$ & $\begin{array}{l}\text { - Many buyers/few suppliers } \\
\text { - Buyer has low \% share of total market for supplier } \\
\text { - Supplier is not at all dependent on the buyer for revenue and has } \\
\text { many alternatives } \\
\text { - Supplier switching costs are low } \\
\text { - Buyer switching costs are high } \\
\text { - Buyers account is not attractive to the supplier } \\
\text { - Supplier offerings are not commoditised and customised } \\
\text { - Buyer search costs are very high } \\
\text { - Supplier has high information asymmetry advantages over buyer }\end{array}$ \\
\hline & & $\begin{array}{r}\text { ATTRIBUTES OF } \\
\text { RELATIVE }\end{array}$ & $\begin{array}{l}\text { JPPLIER POWER } \\
\text { O BUYER }\end{array}$ \\
\hline
\end{tabular}

(6) Robertson Cox Ltd, 2000. All Rights Reserved. (www, robertsoncox.com)

Figure 3 - Client Supplier Information

\begin{tabular}{|l|r|c|c|c|l|}
\hline $\begin{array}{c}\text { Supplier } \\
\text { Pseudonym }\end{array}$ & $\begin{array}{c}\text { Number } \\
\text { of } \\
\text { Spending } \\
\text { Products } \\
\text { Provided }\end{array}$ & Firm Size & $\begin{array}{c}\text { Public or } \\
\text { Private }\end{array}$ & $\begin{array}{c}\text { Type of } \\
\text { Relationship }\end{array}$ \\
\hline Supplier L & $0.93 \%$ & 2 & Unavailable & Private & $\begin{array}{l}\text { Supplier-Dominant } \\
\text { Arms-Length }\end{array}$ \\
\hline Supplier G & $8.06 \%$ & 6 & Unavailable & Private & $\begin{array}{l}\text { Supplier-Dominant } \\
\text { Arms-Length }\end{array}$ \\
\hline
\end{tabular}




\begin{tabular}{|c|c|c|c|c|c|}
\hline Supplier E & $15.79 \%$ & 2 & $\begin{array}{r}705 \text { (Subsidiary } \\
\text { of } \\
\text { 11,949-employee } \\
\text { company incl. } \\
705 \text { ) }\end{array}$ & Public & $\begin{array}{l}\text { Supplier-Dominant } \\
\text { Arms-Length }\end{array}$ \\
\hline Supplier C & $6.58 \%$ & 1 & 10 & Private & $\begin{array}{l}\text { Supplier-Dominant } \\
\text { Arms-Length }\end{array}$ \\
\hline Supplier A & $18.57 \%$ & 3 & $\begin{array}{r}11-50 \text { (Subsidiary } \\
\text { of 478-employee } \\
\text { company) }\end{array}$ & Public & $\begin{array}{l}\text { Supplier-Dominant } \\
\text { Arms-Length }\end{array}$ \\
\hline Supplier F & $0.88 \%$ & 2 & $\sim 400$ & Private & $\begin{array}{l}\text { Supplier-Dominant } \\
\text { Arms-Length }\end{array}$ \\
\hline Supplier K & $\begin{array}{r}\text { No } 2016 \\
\text { Data }\end{array}$ & 1 & Unavailable & Private & $\begin{array}{l}\text { Supplier-Dominant } \\
\text { Arms-Length }\end{array}$ \\
\hline Supplier M & $3.66 \%$ & 2 & $\begin{array}{r}42-521 / 2 \text { year, } \\
10-151 / 4 \text { year, } 7 \\
1 / 4 \text { year }\end{array}$ & Private & $\begin{array}{l}\text { Supplier-Dominant } \\
\text { Arms-Length }\end{array}$ \\
\hline Supplier B & $16.51 \%$ & 2 & $\sim 10$ & Private & $\begin{array}{l}\text { Supplier-Dominant } \\
\text { Arms-Length with } \\
\text { Adversarial } \\
\text { Element }\end{array}$ \\
\hline Supplier H & $17.06 \%$ & 5 & $\sim 3-5$ & Private & $\begin{array}{l}\text { Buyer-Dominant } \\
\text { Collaborative }\end{array}$ \\
\hline Supplier N & $0.99 \%$ & 1 & Unavailable & Private & $\begin{array}{l}\text { Supplier-Dominant } \\
\text { Arms-Length }\end{array}$ \\
\hline Supplier O & $0.99 \%$ & 1 & $4-6$ & Private & $\begin{array}{l}\text { Supplier-Dominant } \\
\text { Arms-Length }\end{array}$ \\
\hline
\end{tabular}




\begin{tabular}{|l|r|r|r|l|l|}
\hline Supplier J & $5.66 \%$ & 2 & $3-5$ & Private & $\begin{array}{l}\text { Supplier-Dominant } \\
\text { Arms-Length }\end{array}$ \\
\hline Supplier I & $1.73 \%$ & 3 & Unavailable & Private & $\begin{array}{l}\text { Supplier-Dominant } \\
\text { Arms-Length }\end{array}$ \\
\hline
\end{tabular}

18 of 23 


\section{Bibliography}

Bastl, M., Johnson, M., \& Choi, T. Y. (2013). Who's Seeking Whom? Coalition Behavior of a Weaker Player in Buyer-Supplier Relationships. Journal of Supply Chain Management, 49(1), 8-28. doi:10.1111/j.1745-493x.2012.03274.x

Benton, W., \& Maloni, M. (2005). The influence of power driven buyer/seller relationships on supply chain satisfaction. Journal of Operations Management,23(1), 1-22.

doi:10.1016/j.jom.2004.09.002

Brown, J.R., Lusch, R.F., Nicholson, C.Y. (1995). Power and relationship commitment: their impact on marketing channel member performance. Journal of Retailing 71 (4), 363-392.

Carey, S., Lawson, B., \& Krause, D. R. (2011). Social capital configuration, legal bonds and performance in buyer-supplier relationships. Journal of Operations Management, 29(4), 277-288. doi:10.1016/j.jom.2010.08.003

Cox, A. (2001). Managing with Power: Strategies for Improving Value Appropriation from Supply Relationships. The Journal of Supply Chain Management, 37(2), 42-47.

doi:10.1111/j.1745-493x.2001.tb00099.x

Cox, A. (1999). Power, value and supply chain management. Supply Chain Management: An International Journal, 4(4), 167-175. doi:10.1108/13598549910284480

Cox, A. (2004). The art of the possible: relationship management in power regimes and supply chains. Supply Chain Management: An International Journal,9(5), 346-356.

doi:10.1108/13598540410560739

Cox, A. (2001). Understanding Buyer and Supplier Power: A Framework for Procurement and Supply Competence. The Journal of Supply Chain Management, 37(2), 8-15. doi:10.1111/j.1745-493x.2001.tb00094.x

Cox, A., Sanderson, J., \& Watson, G. (2001). Supply Chains and Power Regimes: Toward an Analytic Framework for Managing Extended Networks of Buyer and Supplier Relationships. The Journal of Supply Chain Management, 37(2), 28-35. doi:10.1111/j.1745-493x.2001.tb00097.x 
Crook, T. R., \& Combs, J. G. (2007). Sources and consequences of bargaining power in supply chains. Journal of Operations Management, 25(2), 546-555. doi:10.1016/j.jom.2006.05.008

DuHadway, S. An investigation of the impact of trust, knowledge, and dependence asymmetries on relational performance in buyer-supplier dyads. Diss. MICHIGAN STATE UNIVERSITY, 2016.

Dyer, J. H., \& Singh, H. (1998). The Relational View: Cooperative Strategy And Sources Of Interorganizational Competitive Advantage. Academy of Management Review, 23(4), 660-679. doi:10.5465/amr.1998.1255632

El-Ansary, A., \& Stern, L. (1972). Power Measurement in the Distribution Channel. Journal of Marketing Research, 9(1), 47-52. doi:10.2307/3149605

Emerson, R. (1962). Power-dependence relations. American Sociological Review 27, 31-41.

Gomes-Casseres, B. (1997). Alliance strategies of small firms. Small Business Economics 1, $33-44$.

Gundlach, G. T., Achrol, R. S., \& Mentzer, J. T. (1995). The Structure of Commitment in Exchange. Journal of Marketing, 59(1), 78-92. doi:10.2307/1252016

Hunt, S., Nevin, J.R. (1974). Power in a channel of distribution: sources and consequences. Journal of Marketing Research 11 (2), 186-193.

Jennings, P., \& Beaver, G. (1997). The Performance and Competitive Advantage of Small Firms: A Management Perspective. International Small Business Journal,15(2), 63-75. doi:10.1177/0266242697152004

Johnsen, R. E., \& Ford, D. (2008). Exploring the concept of asymmetry: A typology for analysing customer-supplier relationships. Industrial Marketing Management, 37(4), 471-483. doi:10.1016/j.indmarman.2007.05.004

Lorenzoni, G., \& Baden-Fuller, C. (1995). Creating a Strategic Center to Manage a Web of Partners. California Management Review, 37(3), 146-163. doi:10.2307/41165803 
Maloni, M.J., Benton, W.C. (2000). Power influences in the supply chain. Journal of Business Logistics 21 (1), 42-73.

Nyaga, G. N., Lynch, D. F., Marshall, D., \& Ambrose, E. (2013). Power Asymmetry, Adaptation and Collaboration in Dyadic Relationships Involving a Powerful Partner. Journal of Supply Chain Management, 49(3), 42-65. doi:10.1111/jscm.12011

Raven, B. H. (1992). A Power/Interaction model of interpersonal influence: French and raven thirty years later. Journal of Social Behavior and Personality, 7(2), 217. Retrieved from http://stats.lib.pdx.edu/proxy.php?url=http://search.proquest.com.proxy.lib.pdx.edu/docview/129 2303175 ?accountid $=13265$

Spillan, J. E., \& Ziemnowicz, C. (2003). Strategic Management in Small Retail Businesses: The Case of Guatemala. International Small Business Journal, 21(4), 461-478. doi:10.1177/02662426030214005

Stuart, I. (1993). Supplier partnerships: influencing factors and strategic benefits. International Journal of Purchasing and Materials Management 29 (4), 22-28.

U.S. Census Bureau (2014). Number of Firms, Number of Establishments, Employment, and Annual Payroll by Enterprise Employment Size for the United States and States, Totals.

Retrieved from https://www.census.gov/data/tables/2014/econ/susb/2014-susb-annual.html.

Villena, V. H., \& Craighead, C. W. (2016). On the Same Page? How Asymmetric Buyer-Supplier Relationships Affect Opportunism and Performance. Production and Operations Management, 26(3), 491-508. doi:10.1111/poms.12648

Villena, V. H., Revilla, E., \& Choi, T. Y. (2011). The Dark Side of Collaborative Buyer-Supplier Relationships: A Social Capital Perspective. Journal of Operations Management, 29, 561-576. doi:10.2139/ssrn.2220486

Walker, E. (2004). What Success Factors are Important to Small Business Owners? International Small Business Journal, 22(6), 577-594. doi:10.1177/0266242604047411

Wilkinson, I. (1981). Power, conflict, and satisfaction in distribution channels - an empirical study. International Journal of Physical Distribution and Materials Management 11 (7), 12-32. 
Wong, D. (2016). [Powerpoint slides]

Wuyts, S., \& Geyskens, I. (2005). The Formation of Buyer-Supplier Relationships: Detailed Contract Drafting and Close Partner Selection. Journal of Marketing,69(4), 103-117. doi:10.1509/jmkg.2005.69.4.103 